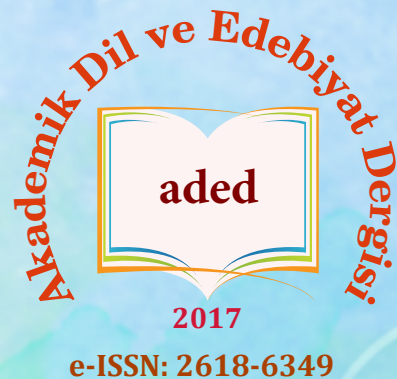

Akademik Dil ve Edebiyat Dergisi Academic Journal of Language and Literature Cilt/Volume: 3, Sayı/Issue: 3, (Aralık/December 2019)

\title{
Güngör Dilmen’in Tiyatrolarında Toplumsal Temalar ${ }^{*}$
}

\author{
Social Themes In Güngör Dilmen's Theaters
}

\section{Ali PULAT* - Segül BAYRAKTUTAN**}

*Dr. Öğr. Üyesi, Uşak Üniversitesi

e-mail: ali.pulat@usak.edu.tr

**YL Öğrencisi, Ușak Üniversitesi

e-mail: ali.pulat@usak.edu.tr

Araştırma Makalesi / Research Article https://doi.org/10.34083/akaded.649748

Sorumlu Yazar/Corresponding Author

Ali Pulat, Uşak Üniversitesi, Fen Edebiyat Fakültesi

ORCID*: 0000-0001-8923-0782

Geliş Tarihi/Received : 22.11.2019

Kabul Tarihi/Accepted : 07.12.2019

\section{Atıf/Citation}

PULAT, Ali; BAYRAKTUTAN, Segül (2019). Güngör Dilmen'in Tiyatrolarında Toplumsal Temalar. Akademik Dil ve Edebiyat Dergisi, 3 (3), 374-393.

DOI: $10.34083 /$ akaded.649748

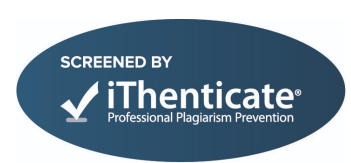

Öz

Güngör Dilmen'in tiyatroları geniş bir coğrafyada zengin tarihi birikim ve evrensel bakış açısıyla işlenmiștir. Yazarın yedi kısa oyunu, yedi gölge oyunu olmak üzere otuz beş basılı tiyatro eseri ve iki adet de masal kitabı vardır. Konularını genellikle tarih ve mitolojiden alan yazar, eserlerinde Mezopotamya'dan Meksika'ya çok geniş bir kültür dünyası sunar. Evrensel nitelikli konuları ele alan Güngör Dilmen'in amacı, yeryüzündeki tüm insanların ortak sorunlarını ve duygularını eserlerine yansıtmaktır. Tiyatroları, tarihteki ve mitolojideki dramatik unsurları kullanarak insanın ve toplumun evrensel nitelikteki sorunlarını irdeler. Canlı Maymun Lokantası ve Deli Dumrul eserlerinde kapitalizmin acımasız yönlerini ele alır. Afyon Savaşı ve Troya İçinde Vurdular Beni eserlerinde sömürgenin insana ve topluma verdiği zararları anlatır. Karagözün Filozofluğu eserinde kültür emperyalizmini, İlse Koch'da irkçıllı̆ı, Toplar ve Paşalar'da demokrasiyi değerlendirir. $\mathrm{O}$, eserlerinde özgürlük, kumalık ve rüşvet temalarına da değinir. İnsanın evrensel değerlerine saldırı mahiyetinde yorumladığı her tür düşünce, sistem ve yaklaşımı reddeden Dilmen, toplumsal temalı tiyatrolarında insanın varoluşunu kendi iradesiyle gerçekleştirebilmesinin kıymetini hissettirmeye çalışmıştır.

Anahtar Kelimeler: Güngör Dilmen, tema, tiyatro

\begin{abstract}
Güngör Dilmen's theaters have a rich historical background and a universal perspective in a wide geography. He has written thirty-five printed plays that consist of seven short plays, seven shadowplays, and two fairy tale books. Güngör Dilmen, whose subjects are generally based on history and mythology, presents a wide cultural World from Mesopotamia to Mexico in his works. Addressing universal issues, Güngör Dilmen's aim is to reflect the common concern demotions of all people on earth to his works. Theaters examine the universal problems of individuals and society by using dramatic elements in history and mythology. Canl Maymun Lokantasi and Deli Dumrul discuss the cruel aspects of capitalism in his works. Afyon Savaşı and Troya İçinde Vurdular Beni focuses on the harm that the colonialism causes to people and society. He discusses cultural imperialism in Karagöz'ün Filozofluğu, racism in Ilse Kochand democracy in Toplar ve Paşalar. Güngör Dilmen also touches on the themes of freedom and bribery in his works. Güngör Dilmen, who rejects all kinds of ideas, systems, and approaches that he interprets as an attack on the universal values of human beings, has tried to make people feel the value of the human being to realize his own existence in his social themed theaters.
\end{abstract}

Key Words: Güngör Dilmen, theatre, theme

${ }^{*} \mathrm{Bu}$ makale Segül Karabulut tarafından hazırlanan "Güngör Dilmen'in Tiyatrolarında Temalar" isimli yüksek lisans tezinden üretilmiştir. 


\section{Giriș}

Güngör Dilmen, 27 Mayıs 1930 yılında Tekirdağ’da doğmuştur. Yazar, ilkokulu Çanakkale ve Biga'da bitirdikten sonra İstanbul Nişantaşı'nda bir İngiliz okuluna yazılır. Liseyi bitirdikten sonra diploma denklik problemleri yaşar (Doltaş, 2010: 10). İstanbul Üniversitesi Klâsik Filoloji Bölümünü bitirdikten sonra Amerika Birleşik Devletleri’nde Yale ve Washington Üniversiteleri'nde sahne 1şığı ve sahne marangozluğu üzerine eğitim görmüştür (Çalışlar, 1995: 165). 1966-1968 yıllarında İstanbul Şehir Tiyatroları’nda başrejisör yardımcılığı yapmıştır. 19701972 yıllarında Durham Üniversitesinde Türkçe dersleri vermiştir. 1980 darbesinden sonra da Şehir Tiyatroları'ndaki görevine son verilmiştir. Güngör Dilmen, uzun bir süre Boğaziçi Üniversitesinde Etimoloji dersleri vermiş ve İstanbul Üniversitesi Devlet Konservatuarında ve Müjdat Gezen Sanat Merkezi'nde öğretmenlik yapmıştır (Doltaş, 2010: 11). Yaşamı boyunca pek çok tiyatro eseri yazan sanatçı, 2012 yılında İzmir'de vefat etmiştir.

Güngör Dilmen'in tiyatroya ilgi duyması lise yıllarına dayanır. Lisede Shakespeare'in "Bir Yaz Gecesi Rüyası"ve "Macbeth" adlı eserlerinden etkilenerek tiyatro yazmaya başlar (Doltaş, 2010: 10). Güngör Dilmen'in sahnede ilk oynanan eseri kısa oyunlarından biri olan Ayak Parmakları, 1958-59 yıllarında Genç Tiyatro tarafından sahnelenmiştir. Midas'ın Kulaklarıoyunu ile yazar, Tiyatro dergisinde birincilik kazanır. 1960 yılında Midas'in Kulakları, Devlet Tiyatrosu tarafindan sahnelenir (Doltaş, 2010: 10).Canlı Maymun Lokantası 1964, Kurban ise 1967 yıllarında Gülriz Sururi Engin Cezzar Tiyatro Topluluğu tarafından sahnelenir (And, 1983: 635-665). Güngör Dilmen'in Devlet Tiyatroları tarafindan oynanan eserleri Akad'ın Yayı, Midas'ın Altınları, Bağdat Hatun, Midas'ın Kördüğ̈̈mü, Deli Dumrul, Ak Tanrılar, Aşkımız Aksaray’n En büyük Yangını, Troya İçinde Vurdular Beni, Hasan Sabbah, Osmanlı Dram Kumpanyası, Kuzguncuk Türküsü ve Ben Anadolu'dur.

Güngör Dilmen, eserlerini genellikle tiyatro türünde yazmıştır. Yazarın tiyatro oyunlarının dışında yalnızca iki masal kitabı bulunmaktadır. Güngör Dilmen'in yedisi kısa oyun, yedisi gölge oyunu olmak üzere otuz beş adet basılı tiyatro oyunu vardır.

Güngör Dilmen, ilk oyunu olarak Midas'in Kulakları'nı kabul eder. Mitolojik malzemeyi kullanarak tiyatroya başlayan Dilmen, bunun sebebini mitoslarda hazır bulunan dramı işleme isteğine bağlar (Çekiç, 2010: 20). Yazar, Anadolu ve Yunan mitolojisinden yararlanır, eserlerinde Ortadoğu mitlerinden izler de görülür. Mitolojinin içerdiği dramatik unsurların gücünden faydalanan yazar, işlediği mitlere evrensel öğeler katarak onları zenginleştirmeyi bilmiştir (Göktaş, 2015: 15).

Güngör Dilmen, Mukadder Yaycıŏglu ile yaptığı söyleşisinde tarihi olayları sıkça kullanmasının sebebini, mitolojide olduğu gibi tarihin içerdiği dramla açıklar. Tarihi olayların içinde barındırdığ 1 dramın, insanların psikolojisine nasıl etki ettiğini eserlerinde aradığını anlatan Dilmen, yalnızca Türk tarihi ile değil Dünya tarihiyle ilgilenmesinin altını çizer. Tevfik Fikret'in "Vatanım rûy-i zemin, milletim nev-i beşer" mısralarını hatırlatan yazar, kendini bir dünya vatandaşı olarak gördüğg̈nü belirtir. Bu sebeple sanatçı, okuyucuya Meksika'dan Japonya'ya, Çin'den İngiltere'ye değin bir coğrafya sunar (Yaycıoğlu, 2005: 133). Yazar, Osmanlı'nın yeni bir devlet düzeni kurma yolunda Meşrutiyet'i ilan ederken yaşadıkları sıkıntılardan Kurtuluş Savaşı günlerini konu eden eserlerine kadar; Ben Anadolu adlı eserinde Tanrıça Kübele'den başlayarak Hürrem Sultan'dan Halide Edip'e değin birçok tarihi kişiliği eserlerinde irdeler.

Tarih ve mitoloji, okuyucu ile olay arasındaki mesafeyi uzaklaştırarak okuyucuya daha geniş bir bakış açısı sunar. Yazar, tarih ve mitolojinin kendisine sağladığı imkânları kullanarak okuyucuya 
ve seyirciye iletisini daha güçlü şekilde verir. Sanatçı, tarihi ve mitolojik kişilerin zaaflarını, korkularını, tutkularını işleyerek karakterleri seyirciyle bütünler (Keçeli, 2003: 19).

Güngör Dilmen'in tarihi oyunları Ak Tanrılar, Bağdat Hatun, Hasan Sabbah, Devlet ve İnsan, Hakimiyet-i Milliye Aşevi, Osmanlı Dram Kumpanyası, İttihat ve Terakki, Galileo'nun Günahları?, İlse Koch, Kuzguncuk Türküsü ve Hezarfen Ahmet Efendi'dir.Sanatçı, tarihi oyunlarında geçmişte yaşanan olaylardan yaşadığı döneme ilişkin atıflarda bulunur. Yazarın tarihi oyunlarında Batının emperyalist ve yayılmacı anlayışının eleştirileri sıkça işlenir. Batının kendi menfaatlerini diğer ulusların yaşamsal haklarının üstünde tutarak benmerkezci yaklaşımı başlıca eleştiri unsurudur. Güngör Dilmen'in oyunlarında Amerika ve Avrupa'nın eleştiriye uğradığı bir diğer konu kapitalizm olur. Sanatçı, Batının kapitalist düzeninin en net eleştirisini Canlı Maymun Lokantası adlı eserinde yapar. Batı dünyasının yayılmacı ve emperyalist tutumlarını sergilerken gösterdikleri ikiyüzlüce davranışlar gözler önüne serilir. Sömürge yapmak için uğraştıkları küçük devletlerin menfaat ve özgürlüklerini korumayı görev edindiklerini söyleyerek onlardan maddi olarak yararlanmaları, Batının ikiyüzlü davranışlarına somut örnek olarak sunulur.

Güngör Dilmen, toplumsal eleştirilerini yalnızca Batı dünyasına özgü kullanmaz. Doğu’nun mistik ve dini inançlara kapılarak tembelleşmesini eleştirir. Yazar, ideal dünya düzeninin aklı ve bilimi esas almakla sağlanabileceğini düşünür. Akıl ve bilimin karşısına her türlü inancı yerleştiren sanatçı, çatışmadan daima bilimi üstün çıkarır. Yazar, Doğu devletlerini kendi kültürlerine sahip çımmamasını da eleştirir. Doğu toplumu, kendi kültürlerini korumayarak Batının kültür emperyalizmine açık hale gelir. Sanatçı, kendi kültürlerini korumayan devletlerin yıkılmaya mahkum olduğunu ileri sürer. Güngör Dilmen'in pek çok eserinde aydın kesimin eleştirisine rastlarız. Aşırı Batı hayranı olan aydınlar, benlikleri tamamlanamamış ve toplumdan uzak bireyler olarak gösterilir. Aydınların kendi toplumlarının kültürüne sahip çıkmasını savunan yazar, aydınlara gerekli özgür düşünce ortamının oluşturulmasını şart koşar.

Dilmen'in mitolojik oyunları ise, Midas'ın Kulakları, Kurban, Midas'in Altınları, Midas'in Kördüğümü, Deli Dumrul, Akad’ın Yayı, Ben Anadolu, Galatea ve Pigmalion, Sokrates "Bulutlar"da, Troya İçinde Vurdular Beni, Şan Şeref Ün: Amfitrüon ve Girit Masallari'dır. Yazar, mitolojik malzemeyi kullanarak seyirciye günün aktüel olayları yorumlama imkanı sunar. Sanatçı, Troya İçinde Vurdular Beni oyununda Tanrıların savaşı spor müsabakası gibi izlemesini büyük devletlerin tutumuna benzetir. Eserde, Çanakkale Savaşı'na gönderme yapılarak "emperyalist hırs" yüzünden ölen binlerce gencin arkasından yazılan bir ağıt niteliği taşır (Dilmen, 2012: 8).

Güngör Dilmen'in eserlerinde önem verdiği konulardan bir tanesi de kadındır. Yazar, toplumun kadına dayattığı rolleri eleştirirken kadının topluma başkaldırısını olumlar. Başlık parası, imam nikahı, çocuk gelin gibi kavramların karşısında duran yazar, kadının erkekle aynı haklara sahip olması gerektiğini savunur. Kadınlara karşı meslek ayrımcılığı ve kadının özgürlüğünün sınırlanması eleștiri unsurlarıdır. Kadının annelik vasfı yüceltilirken kadının toplumlar üzerindeki gizli liderliği ön plana çıkarılır. Yazarın, olumsuz yönüyle ele aldığı tek kadın karakter Bağdat Hatun'dur. Kadının toplumsal rolü ister kraliçe ister hayat kadını olsun, hepsinin hayata karşı duruş sergileyen bir karakteri vardır (Keçeli, 2003: 27).

Güngör Dilmen'in eserlerini başarılı kılan öğelerden bir tanesi de yazarın kullandığı şiirsel dildir. Sanatçı, Mukadder Yaycıoğlu ile olan söyleşisinde kullandığı şiirsel dili "ritmik dil” olarak tanımlar. Şiirselliği oyununa sokmasının sebebini, düzyazı ile onlarca cümlede söyleyebileceği iletiyi şiirle bir çırpıda verebilmesi olarak açıklar (Yaycıoğlu, 2005: 130). 
Sanatçı, eserlerinde görselliği bir bütün olarak görür. Tiyatroda şiiri, süslü bir dil olarak kullanmadığını, dilin görselliği dışında sahne öğelerini de efektif kullanmak gerekliliğini ifade eden yazar, 1şık, ses, sahne gereci ile şiirselliği kullanmak gerektiğini ifade eder ( Çekiç, 2010: 21).

Güngör Dilmen, Brecht'le birlikte ülke tiyatrosunun epik tiyatroya kapılmasının eleştirisini yaparken kendisinin hiçbir akıma kapılmadığını söyler. Yazar, oyunlarında sıklıkla göstermek istediği "pantarhei-herşey akıyor" kavramını ortaya koyar ve tiyatrolarını insan hayatına bütünlük verme çabasıyla kaleme aldığını açıklar (Yaycıŏlu, 2005: 134).

\section{Tema Kavramı Üzerine}

Edebiyat araştırmacıları, tema kavramını tanımlamada farklı açıklamalar getirmişlerdir.

"Tema: Bir esere hâkim olan fikir ve his" (Doğan 1990: 1077).

“Olay örgüsünü meydana getiren parçalar arasındaki çatışma veya karşılaşmanın en kısa ve kesin ifadesi temadır” (Aktaş 2013: 69).

Nurullah Çetin, tema yerine izlek kavramını kullanır. Çetin, izleği, romanın üzerine temellendiği konunun yazarın duygu ve düşüncesinde öznel bir yargı halinde ortaya konan sentezi olup, romanın nihai hedefi ve romancının asıl amacıdır, șeklinde açılar (Çetin, 2008: 123).

Nurullah Çetin, eserin izleğini ve konusunu şöyle ayrıştırır:

"Konu genelde bir edebi tür, özelde ise roman için nesnel ve genel bir alt yapıdır, romanın üzerine temellendiği zemindir ve o edebi türün etrafında örüldüğü ham malzemedir. Romanc1, hemen her yazarın kullanmakta özgür olduğu bu malzemeden yola çıkarak özgün görüşünü, düşünce ve teklifini ispatlanabilir bir yargı halinde romanlarına sindirmiştir. Okuyucunun romanın bütününe sinmiş olan bu ispata açık hükmü bir iki cümle halinde ortaya koyduğu şey, izlektir” (Çetin, 2008: 123-124).

Çalışmamızda Güngör Dilmen'in tiyatro eserlerinde ele aldığı toplumsal temalar alt başlıklar halinde verilecektir.

\section{Kapitalizm}

Güngör Dilmen, Canlı Maymun Lokantası'nda kapitalizmin ilkelerini derinlemesine eleştirir. Kapitalizmin etkisinde olan Batı topluluğu, yaşamlarını maddi gücün tesiri altında yürütür. Batı dünyası, paranın verdiği güçle her türlü insanlık dışı davranışı kendilerine verilmiş hak olarak görür. Güngör Dilmen, Batı dünyasının kapitalist düzenini petrol tüccarı ve zengin bir aile olan Jonathanlar aracılığı ile eleştirir. Bay ve Bayan Jonathan, dünya üzerindeki farklı lezzetleri tecrübe etmek istemektedirler. Bu amaçla geldikleri Hong Kong'ta canlı maymun beyni yemek için bir lokantaya gelirler. Servise hazırlanan maymun lokantadan kaçar. Ozan Wong, Amerikalılara maymun yerine kendi beynini teklif eder. Hong Kong'da kapitalist sistemin unsurlarının işleyebilmesi için bütün çarklar yerine oturmuştur. Parası verildiği takdirde bir insan beynini yemek bile suç olmayacaktır.

Garson ve Avcı Çoo, Bay Wong'u delikli maymun masasının altına sokarlar. Bayan Jonathan, Wong'un kendilerine darıldığını düşünür. Bay Jonathan ise, Wong'un hakkını fazlasıyla ödediklerini söyler. Jonathan, yeryüzündeki her şeyin kendi mutlukları için olduğunun altını çizer. 
Ona göre; gücü elinde bulunduran mutluysa ve karşılığını ödediyse, başka hiçbir şeyin anlamı yoktur.

Güngör Dilmen, Deli Dumrul adlı eserinde kapitalist dünyanın toplumlar üzerinde yarattı̆̆ 1 sömürüyü ve zorbalığı eleştirir. Yazar, gücü karşı çıkmaya yetmeyen halk üzerinden zorbalıkla menfaat elde eden sermaye sahiplerine ve yöneticilere göndermede bulunur.

Deli Dumrul, suyu tükenmiş bir çay üzerine kişisel menfaat elde etmek amaciyla bir köprü inşa eder. Köprü kurulana kadar ulaşımını rahatlıkla sağlayan halka zorbalık yaparak köprüden geçişi şart koşar. Dumrul; köprüden geçenden 30 akça para alırken geçmeyenden 40 akça para alır. Halkın bir kısmı bu duruma karşı çıksa da güçleri Dumrul'a yetmediğinden parayı vermeye razı olurlar. Onun köprüsünden kalabalık bir kafile olarak Canguzoğlu'nun Bezirganları geçer. Dumrul, kafileden de haraç kesmek istese de gücü onlara yetmez. Bezirganlar, ağalarının zengin olduğunu söyleyerek ona haraç vermezler. Dumrul, ağalarının kim olduğunu merak eder. Dumrul; kendisinden daha zorba olan bir tüccarla karşı karşıya geldiğinin farkındadır. Canguzoğlu, dünyanın farklı yerlerinden getirdiği ucuz malları değişik ülkelere satmaktadır. Yazar, sermaye sahiplerinin Anadolu halkını kullanarak para ve güç elde ettiğini gözler önüne sermektedir. Halkın imkanlarından yararlananların topluma hiçbir hizmet sağlamadan yalnızca menfaat peşinde koşmalarını eleştirir.

\section{Sömürgecilik}

Güngör Dilmen, eserlerinde Avrupalıların sömürgeci faaliyetlerine karşı çıkar. Yazar, Afyon Savaşı adlı eserde İngilizlerin diğer devletleri kendi maddi amaçları doğrultusunda ikiyüzlüce davranarak baskı altında tutmasını eleştirir. İngilizler, sömürgesi Hindistan'da oldukça fazla miktarda afyon yetiştirmektedir. Yetiştirdikleri afyonu, kendi halkına zarar vermemesi için kendi ülkelerine sokmadan başka ülkelere satarak maddi kazanç elde etmek isterler. İngiliz Kraliçesi ve Elçi, afyon pazarı hakkında konuşurlarken afyonu İngiltere'ye sokmanın dinlerine uygun olmadığını söyler. Afyonla başka ülkelerdeki insanları zehirlemeleri de dine aykırı olmasına rağmen maddi kazanç sağlayacak olmaları, onlar için öncelikli hedeftir. İngilizler, afyon satıp para kazanmak için nüfusu çok kalabalık olan Çin'i seçerler. İngilizler Çinlilere afyon satmakla hem para kazanır hem de Çinliler düşünemez ve çalışamaz duruma geldikleri için İngilizlere karşı tehdit olmaktan çıkarlar. Çinliler afyon tuzağına düşerek nüfusunu etkin kullanamaz ve güçlü bir devlet olamazlar. Çinli Lin, ülkenin durumunun farkına vararak büyük çabalar göstererek afyonun ülkeye sokulmaması kararını çıkarttırır. Yazar, Çin İmparator'unun Kraliçe Victoria'ya yazdığı mektubu Lin'e bir replik olarak söyleterek duruma hem gerçekliği sokar hem de Batı dünyasının ikiyüzlülügünü gözler önüne serer:

"Lin - Ey, Ak Barbarların Ecesi, işitiriz, senin ülkende afyon kullanmak yasalarla önlenmiştir. Demek, afyonun ne denli zararlı olduğu sizce de pek iyi biliniyor. Ama gemilerinizle Çin'e kaçak olarak sokmakta bir sakınca görmüyorsunuz. Bu davranışınız kendi să̆lı̆̆ınıza nice önem verdiğinizi ancak başka insanların yaşamın hiçe saydığınızı gösterir. Kazanç uğruna, başkalarına vereceğiniz zararlara göz yumuyorsunuz. Bu hangi töre, hangi inanca sığar? İtici geliyor insan duyarlığına. Sizden bin yıl önce biliriz ki uygarlık bu değildir" (Dilmen, 1996, 97).

Güngör Dilmen, Troya İçinde Vurdular Beni oyununda mitolojik öğeleri kullanarak günümüz savaşlarını ve etkilerini göstermek ister. Oyunda Tanrıları büyük devletlerle özleştiren yazar, Troya ve Akha gibi devletlerin kışkırtmalar sonucunda yaşadığı yıkımları örnekler. Tanrılar, Troya Savaşı'nı gökyüzünden izlerler. Maç izler gibi tezahürat ederler ve içki içerler. Yeryüzünde yaşanan dram, Tanrılar için bir eğlence halini alır: 
"Zeus - Seyrediyoruz ama acıyoruz da en azından.

Şu ölümlüler olmasaydı çok yavan olurdu

Bizim ölümsüzlüğümüz...” (Dilmen, 2000, 160).

Tanrılar, savaşlar esnasında büyük devletlerin içinde bulunduğu aymazlık halini alır. Tanrılar gibi büyük devletler de savaşta yaşanan dramlara uzaktan acımakla yetinirler. Tipkı Tanrıların savaşa sebep olduğu gibi büyük devletler de savaşlara sebep olurlar ve yalnızca uzaktan seyretmekle yetinirler. Yazar, mitolojiden faydalanarak günümüzdeki savaşların bir izdüşümünü yansıtır:

"Athena - Hem bu savaşa neden ol, hem de savaş kavramına karşı çı!!” (Dilmen, 2000, 161).

Yazarın büyük devletleri eleştirdiği bir başka konu, savaş konusundaki ikiyüzlülüktür. Medeni görünen ve şiddete karşı görüşler belirten devletlerin, aslında savaşları çıkaran sebepleri yaratan devletler olduğunu gösterir.

\section{Kültür Emperyalizmi}

Güngör Dilmen, Karagöz’ün Filozofluğu adlı kısa oyununda Batı dünyasının riyakarlığını seyirciye sunarak Avrupalıların yaptığı kültür tahribatını tema olarak almıştır. Yazar, Türklerin abartılı Batı hayranlığı ve Batılılaşma çabasını da eserinde işlemiştir.

Güngör Dilmen, eserinde Avrupalıların gerçekleştirdiği kültür tahribatını tema olarak işler. Finkellerin Karagöz'ün evinde yaptığı değişikler, ülkede yabancıların tarafından gerçekleştirilen tahribatın minimal ölçekteki örneklerdir. Finkeller nezdinde Avrupa'nın ülkenin tüm değer anlayışının ve kültürünün yağmalanması eleştirilir. Asırlık konağın değerleri, Batılı komşuların gelmesiyle birer birer silinir. Asmalı konak olarak anılan evin asmasını kesen Bayan Finkel, yerleştiği evin sembol değerlerini hiçe sayarak öncelikli olarak kendi konforunu düşünmektedir. Asmanın yapraklarını ve asmaya çıan kedilerle uğraşmak istemeyen Bayan Finkel, Karagöz'ün karısının tepkisine aldırış dahi etmez. Bayan Finkel, Batılı kapitalist anlayışına göre, eve para verdiği için her şeyi yapabileceğini düşünür:

"Karagöz'ün Karısı - Bu muydu senin uygarlı̆̆ı??

Finkel - Taze dolar vermişiz, satın almışız bu evi. Şimdi onarıyoruz” (Dilmen, 2010, 138).

Finkeller, konağı değiştirmeye evin içiyle devam ederler. Yaptıkları değişiklikleri, evin özelliklerini düşünmeden gerçekleştirirler. Bu sebeple, evin onarımında çalışan işçinin bacağı Karagöz'ün tavanından aşağıya sarkar, mutfaktan mazot iner ve Karagöz'ün evini su basar. Finkeller, Karagözlerin evine verdikleri hasardan dolayı pişman olmazlar. Aksine, evi su bastığ için faturalarının yüksek geleceğini düşünürler. Yazar, Avrupa'nın bencil bakış açısını seyirciye aktarır:

"Karagöz'ün Karısı - Aşağıdan almak hep bizim payımıza düşer. Ne de olsa onlar komşu ve yabancı" (Dilmen, 2010: 141).

Avrupa’nın bencilliği, verilen zararın tanziminde de devam eder. Finkeller, Karagöz’ün evinin tamirini zamanlarının kısıtlı olduğu gerekçesiyle kendilerinin yaptırmasını ister:

"Finkel - Ah çok yoğunuz. Zaman bizim için çok önemli.

Karagöz - Zaman yalnız Finkel familyası için değerli” (Dilmen, 2010: 142). 
Güngör Dilmen, Avrupa'nın Türk tarihini kendi menfaatlerine göre tahrip etmesini eleştirir. Bay Finkel, Osmanlı tarihçiliği yapmaya başlar. Osmanlı ile ilgili gerçekleri çarpıtarak sunmaya çalışır. Cumhuriyet'in değerini düşürmeye çalışarak Mustafa Kemal Atatürk'ün ideallerini 'rüya' olarak tanımlar. Yazar, Avrupalıların Neo Osmanlıı bir anlayış ortaya çıkararak Atatürk ilkeleriyle çatışan iki grup oluşturulmaya çalıştıklarını sezdirir. Bay Finkel, ülkenin durumunu çarpıtarak Türkiye Cumhuriyeti’nin artık ne Osmanlı’nın ne de Atatürk'ün rüyasının peşinde olduğunu iddia eder:

"Finkel - Geleceğin bir tarihçisi, geriye bakıp, bugünü büyük bir resmin içinde bir an gibi gördüğünde, Türkiye Cumhuriyeti'nin sonunda Mustafa Kemal'in rüyasını artık vurgulamaya ihtiyacı olmadığını fark ettiğini ve onu -kendisinden önce Osmanlı İmparatorluğu'na destek olan Osman'in rüyası ve diğer efsanelerle birlikte- tarihin derinliklerine terk ettiğini keşfedebilirler" (Dilmen,2010: 146).

Karagöz, Finkel'in Mustafa Kemal'in ülke için gerçekleştirdiklerini rüya olarak vurgulamasına tepki gösterir. Tarihi tahribatta çeşitli tezlerde bulunan Avrupalılar, Finkel nezdinde eleştirilir.

Finkeller, konağın üst katını satın aldıktan sonra evin tamamını satın alıp Karagöz’ü kapıcı yaparlar. Yazar, kültürüne ve benliğine sahip çıkamayan toplumların kendi ülkelerinde söz sahibi olmaktan mahrum olacakları görüşünü yansıtır:

"Şeytan Tasviri - Çă̆ımızda bunun adı en Batılı adı Finkelcilik olabilir ancak" (Dilmen, 2010: 148).

\section{Bilim ve Akılcılık}

Güngör Dilmen, eserlerinde pek çok kez aklı, dini ve mistik inançların önüne koyar. Dünya düzeninin inançlarla geliştirilemeyeceğini, aklın ve bilimin ortak hareket etmesiyle medeniyetlerin yükselebileceği iletisini seyirciye sunar.

Aztekler bazı sanat dallarında çok gelişmiş olmasına rağmen "Ak Tanrı"nın döneceği inancına kapıldıktan sonra bilime yeterli önemi vermemesiyle geri düşerler. İspanyol istilacıları, Ak Tanrı olarak yorumlayarak kapılarını açan Montezuma ülkesinin yıkımına sebep olur. Düşenkartal, Montezuma'yı ülkenin geleceği için hurafelere kapılmaması gerektiği konusunda uyarmış olmasına rağmen Montezumaaklı ve bilimi öne koymamıştır. Yazar, hurafelere ve dini inançlara saplanıp kalan ulusların aklı ön plana çıarmadığı sürece geri kalacă̆g iletisini seyirciye verir.

Güngör Dilmen, Midas’ın Kördüğümü adlı oyununda devletlerin yıkılmasının nedenlerini irdelemiştir. Yazar, devletlerin çözülmesinin sebebini yoz inançlara körü körüne bağlllık olarak görmüştür.

Güngör Dilmen, eserinde Kral Midas'ın dedesi Gordios'un kağnısındaki düğümü çözmeye çalışırken devlet işlerini aksatması sonucunda devletin yıkıma uğramasını konu edinir. Midas, ülkede herkesin kördüğümle ilgilenmesini ve ülkenin en önemli işinin kördüğümü çözmek olduğunu ilan eder. Midas, dügümü çözmek için düştüğü yoz inançlarıyla ülkenin ekonomi, bilim, sanat ve savunmasını durma noktasına getirir. Bilginler, yalnızca düğümü çözme üzerine düşünür. Ülkede özgür düşünce ve felsefenin önü tıkanmıştır. Midas, vezirinin ve kızının ülkenin gerçek sorunlarıyla ilgili uyarılarını görmezden gelir. Ülkenin hazinesinde altın kalmamış, savunma giderleri kördügüum giderlerine harcanmıştır. Frigya’nın düşmanları ülkenin zayıf düştüğünün farkındadır. Kimmerler, Frigya'ya işgal düzenleme hazırlığındadırlar. Midas, savaşın başlamak üzere olduğunu bildiği halde dügümle ilgilenmeye devam eder. Ulak, Kimmerlerin ülkenin 
kapılarına dayandığını duyurur. Savaşı kaybetmek üzere olan Midas, kördügüumün başından ayrılmaz. Kimmerlerin komutanı Tuğdan, Midas'ın bulunduğu Gordios'un kümbetine gelir. Midas, kördügüm hala durduğu için savaşı kaybettiğine inanamaz. Tuğdan, Midas'in yıllarca uğraşıp çözemediği kördügümü kılıcıyla kesip atar. Midas, kördügümün ipiyle kendini asarak intihar eder. Gordios'un bilim, sanat ve iş gücüyle inşa ettiği Frigya, Midas'ın yoz inançlara kapılmasıyla son bulur. Midas, hatasının bedelini ülkesinin dağılması ve kendi canıyla öder:

"Tuğdan - Sen bilici ocaklarına danışırken

benim çaşıtlarım,

Gordium surlarını ölçüp biçiyordu

savunakları koruganları içten çökertiyordu" (Dilmen, 2016: 260).

Güngör Dilmen'in eserinde eleştirdiği bir diğer konu, yoz inançlardan menfaat elde etmeye çalışan kimselerdir. Bekçi, Gordios’un kümbetini koruyan bir kişidir. Gordios’un kağnısındaki dügümü esrarlı hale getirerek orayı türbe haline getirerek menfaat elde etmektedir. Halk, Gordios'un kağnısının başına gelerek adaklar sunar, hastalar, iş arayanlar kümbetten medet umarlar:

"Bekçi: - Aman hiç çözülmesin

düğ̈̈mü görmeye gelenler eksilmesin

ben de düğ̈̈mün gölgesinde

geçinip gidiyorum işte” (Dilmen, 2016: 226).

Yazar, ülkenin gelişmesinin önündeki en büyük engel olarak yoz inançları ve insanların inançlarını sömürerek menfaat elde eden kimseleri görür. Bekçi, Frigya savaşı kaybedip kördügüum çözüldüğünde kümbete kimsenin uğramaması üzerine düğümü tekrar kendisi atar. Bekçi, inanç sömürüsü üzerinden geçimini sağlamaya devam eder.

Frigya’nın yıkımının ardından uzun yıllar geçer ve Büyük İskender çağı başlar. Bekçi, büyük bir hükümdar olması için Büyük İskender’in düğümü çözmesi gerektiğini söyler. Büyük İskender, dügümü çözemez ve başında düşünmeye başlar. Büyük İskender, yoz inançlara kapılıp büyük bir hükümdar olma şansını kaybeder.

Güngör Dilmen, Akad'`n Yayı adlı oyununda ideal dünya düzeninin dini inançlarla değil, insan aklıyla oluşturulabileceğini savunur. Akad, Tanrılara bağlı ve Tanrıların buyruklarını okuyarak özümsemeye çalışan bir gençtir. Akad, Tanrıların buyrukları arasında örtüşmeyen noktalar olduğunu fark eder ve bunun sebebini Tanrılara sorar. Tanrılardan mantıklı cevap gelmeyince onlara olan inancında bir azalma olur. Akad, aklını ve zihnini yorarak Tanrıların hükümlerinin her zaman insanların iyiliğine olmadığını, Tanrıların kendi varlıklarını ve değerlerini sürdürebilmek için sözler söylediklerini anlar. Akad'ın Tanrılara güveni sarsılmıştır. Akad, elinde bulundurduğu yayın yanlış ellerde bulunduğu takdirde insanlığın sonunu getirebileceğini anlar. Akad, Yatpan'ı elindeki yayı hiç kullanmadan Kenan ilinde yargılanması için Yatpan'ın rızası ile getirir. Eserde Akad'ın Yatpan'ı kılıcını kullanmadan zekasıyla ikna etmesi vurgulanır:

"Yatpan - Yüreğime ne yakın geldin Akad

Ben çok yalnızdım mor dağlarda

Kendimi ağaçlara kayalara karıştırırdım hep

kara bir suydum bazen

nereye akacă̆ımı bilemezdim

Şimdi sen geldin, yavaş yavaş kendimi anlamaya

başladım.

Senin için yapmayacağım şey yok" (Dilmen, 1998, 125). 
Halk, Yatpan'a çeşitli hakaretler yağdırarak rahatlar. Halk, Akad'ın elindeki yayı kullanarak komşu devletlere hükmetmesini ve savaşlar kazanmasını ister. Akad, bunu asla yapmayacağını belirterek halka bunu yapmaları halinde Yatpan'dan farkları kalmayacağını söyler. Yatpan, halka karşı gücünü kullanırken kendilerinin mağdur olduğunu hatırlatır. Güç kendi ellerinde bulunduğunda zalim olmayı kafaya koyan halk, Akad'ın üzerine yürür. Akad, yayı halkın eline geçirmesi halinde insanlığın tehlikede olduğunu bildiğinden halkı püskürtmek için yayı ilk kez kullanmak zorunda kalır. Halkın hükmetme isteğinin Tanrılardan kaynaklandığını anlayarak Tanrıların ağacına gider ve Tanrıça Anat dışındaki tüm Tanrıları öldürür. Tanrıları yok ederek insanlığın yalnızca aklını ve bilimi kullanarak ideal dünya düzenine kavuşacağını belirtir. İnsanlar, Tanrılar olmadan kendi kaderlerini kendileri oluşturacaktır.

Akad, Anat'ın dolduruşuna gelen Yatpan tarafından öldürüldükten sonra suya atılır. Aklın üstünlügünü temsil eden Akad'ın öldürüldükten sonra suya atılması yeniden dirileceğinin işaretidir. Yazar, aklın üstünlüğünün her zaman yeniden doğacağını simgeler ( Altun, 1999, 82).

Galileo'nun Günahları? adlı oyunda ise Galileo, inancı ve bilimi karşıt kavramlar olarak görür. İki olgunun dinamiklerinin ve çıkış noktalarının farklılığını özümser. Teleskop, Galileo'nun bilim ve inanç hayatında önemli bir yer tutar. İcat ettiği teleskop sayesinde gökyüzünü gözlemleme şansı yakalar. Gözlemlerinin sonucunda Dünya'nın Güneş’in etrafında döndügünü bulur. Bu buluş, dini inançlarla örtüşmemektedir:

"Dünya evrenin merkezi değil, Güneşin çevresinde bir uydu. Kopernikus’un öngördü̈̆̈̈ gibi. Ama bu Aristotelesci evren görüşüne aykırı. Kutsal betiklere de aykırı" (Dilmen, 2009: 18).

Galileo, arkadaşı Sagredo'nun düzenlediği partide din ve bilim üzerine konuşmalar gerçekleştirir. Galileo, ölümden sonraki yaşamın gerçekliğine inanmamaktadır. Kızı Virginia ise, bu düşüncenin dine aykırı olduğunu hatırlatır. Virginia, ahiret hayatına inanmayanlar için inancın ya da Tanrı'nın bir anlamı olamayacağını ileri sürer. Galileo, evrenin varlığının Tanrı’nın bir sahnesi olduğunu söyler. İnsanlık, evreni çözümleyebildiği kadar varlığını anlamlandırabilecektir:

"Galileo - Tanrı'nın sonsuz bir sahnesi var. Uzay diyorlar adına.

Soracağız...sonsuzcasonrasızca.

Biz kimiz bu acunda?

Yaşam, senin ona verebildiğin anlamdır ancak" (Dilmen, 2009: 47).

Sagredo, Galileo'ya partide takması için güneş maskı hediye eder. Sagredo, Nazım Hikmet'in dizeleri ile "Dostlar arasındayız, güneşin sofrasındayız" (Dilmen, 2009: 48) diyerek Galileo'yu onurlandırır. Bayan Sagredo ise, Galileo'ya bir yerküre verir. Galileo, yerküreyi kendi etrafında döndürmeye başlar. Dünya'nın Güneş etrafında dönmesi, dini düşüncelere aykırı olduğu için din adamlarının hoşuna gitmeyecektir. Galileo, yaptığı hareketin arkasındadır. İnancın, bilimin önünde yok oluncaya kadar zayıflayıp geri adım atacağını belirtir. Bilimin dilinin matematik olduğunu ancak bu dili bilmeyenlerin inanç çıkmazında dolandığını düşünür:

"Galileo - Bilim kendi inancını yaratır...gerçekten bilim ise.

Evren Betiği apaçık durur, onu okumak isteyenlerin önünde.

Ancak o betiğin dili matematiktir, abecesi üçgenler, kareler, dikdörtgenler, açlar, daireler, doğrusallar, eğrilerdir. Bu dili çözemeyenler, körler gibi dolanırlar varlığın labirentlerinde” (Dilmen, 2009: 48-49).

Galileo, Aristoteles'in bir peygamber olmadığını, ayrıca peygamberlerin de yanılabileceğini iddia eder. Ona göre; İsa Peygamber çarmıha gerildiğinde "Tanrım beni niye terk ettin" (Dilmen, 2009: 
49) diyerek Tanrı'nın varlığından şüphe duymuştur. Bu sözler, peygamberlerin de yanılabileceğinin bir göstergesidir.

Galileo, İncil'in kendisine yalnızca cennete gitme yollarını öğreteceğini söyler. İncil, gökyüzünde hangi bilimsel olayların yaşandığını ve gezegenlerin hareketlerini kendisine öğretemez. Gök cisimlerinin kusursuz maddelerden oluştuğunu bilen Galileo, bu maddeler üzerinde herhangi bir canlının yetişip yetişemediğini sorgular. $\mathrm{O}$, pek çok nimet veren toprağı en soylu varlık olarak kutsayarak dolaylı bir şekilde uzayda yaşamın gerçekleşme olasılığını tartar:

"Galileo- Hangi güzelliği öğretebilir bana İncil

yüreğimin bana daha önce söylemediği?

Insan beyninin en ürkünç gizini söylüyorum şimdi:

Din elden gider, us devreye girdi mi...

(Olumsuz uğultu)

Selam size Sezar Borjialar, Lükreşialar

görkemli bir kerhaneye dönüşmüş papalık sarayı

papazların köseleye dönmüşyürekleri

nefretimle kutsuyorum sizleri" (Dilmen, 2009: 57).

Yazar, sahnedeki din ve bilim karşıtlı̆̆ını vurgulamak amacıyla halkın şamatalı konuşmalarından yararlanmıştır. Halk, fikra şeklinde konuşmalar sürdürür. Halkın söylediklerine göre, Papa, Galileo'ya teleskopla göklerde melekleri görüp görmediğini sorar. Galileo, melekleri görmediğini söyler. Bunun üzerine Papa, bunu kimseye söylememesini, yoksa dinin elden gideceğini tembihler. Galileo, aynı soruyu soran Kopernikus’a, melekleri gördügünü söyler. Kopernikus, bunu kimseye söylememesini, yoksa bilimin elden gideceğini belirtir. Halk, Galileo'nun iddialarının sonunun nereye gideceğini merak etmektedir. Galileo, Sagredo'nun toplantısındaki konuşmalarından sonra birçok uyarı mektubu alır. Bu uyarılardan bir tanesi de Engizisyon Kardinali Bellarmino'dan gelir. Bellarmino, kiliseye karşı işlediği suçu işleme koyduğu takdirde Galileo'nun öldürüleceğini belirtir. Galileo'nun işlediği suçu “bilimsel günah”(Dilmen, 2009: 59) olarak adlandıran din adamı, Galileo'dan Kopernikus’un adını bir daha ağzına dahi almamasını ister.

Galileo, Söyleşi ve Ölçümler/Deneyler adlı eserlerinde öne sürdügü düşünceleri sebebiyle 3 sorgulayıcı tarafından yargılanır. Sorgulayıcılar, Galileo'yu suçsuz ilan ettikleri takdirde inanç dünyasının kaybedip bilimin öne çıkacağı fikrinde uzlaşırlar. Onun İncil’e karşı geldiği için özür dilemesini, aksi takdirde cezasının ölüm olduğunu bildirirler. (Bunun üzerine) Galileo, yakılarak öldürülmekten kurtulmak için bilimsel olarak kanıtladığı Dünya’nın Güneş etrafında dönüşünü reddeder.

Güngör Dilmen, Hezarfen Ahmet Efendi adlı kısa oyununda Osmanlı'daki keşifleri bilimsel gerçeklere uygunluk, dine uygunluk ve Padişahın isteklerine uygunluğu konusunda ele alır. Yazar, eserlerinde bilimi, inançlara üstün tutarak bilimi ve aklı yüceltir.

Güngör Dilmen, bir rivayet olarak bilinen Hezarfen Ahmet Efendi'nin Galata Kulesi'nden uçması olayını temel alır. Hezarfen Ahmet Efendi'nin herhangi bir fen okulunu bitirmeden, mühendislik gerektiren kanat yapma işlemini gerçekleştiremeyeceği düşünülür. Hezarfen Ahmet'in uçtuğu iddiasını Newton'un yer çekimi kanunun da izin vermeyeceğine dikkat çekilir. Hezarfen Ahmet'in ilk uçuşu yaptığına inanan "Neo Osmanlılar", bilimsel gerçekliğe davet edilir. Rivayetlerin öncelikli olarak bilimin doğruları tarafından incelenmesi, bilimin her konuda üstün kılınmasını sağlar. 
Yazarın eleştirdiği bir başka konu, bir keşif peşinde olan Hezarfen'in Şeyhülislam'dan izin alması gerekliliğidir:

"Yardak - Başından çarpık ya... Doğrultalım konuyu.

Hezarfen Efendi, selamsiz sabahsiz

Ve Şeyhülislam'dan almadan fetva

Galata Kulesi'nden kanat açtı karşı kıyıya

Karşı kıyı Asya” (Dilmen, 2010: 132).

Oynatıc1, Hezarfen'in uçuşunu duyan Padişah 4. Murat'in gururlanarak Hezarfen'i ödüllendirdiğini anlatır. Padișah’a sinsice yaranarak kendine menfaat sağlayan bir şair, Padișah’ı doldurarak Hezarfen'in ceza almasını sağlar. Yazar, Hezarfen'in keşfini desteklemesi gereken Padişahın, kıskançlıklar ve entrikalarla önüne geçmesini eleştirir:

\section{"4. Murat - Yerden yekinip gökyüzüne uçmalar kimin haddine?}

Ben ki bir hayli eksilmiş de olsa bir cihan padişahıyım hala Tanrının gölgesi yeryüzünde.

Bugün gökyüzünde uçan adem, bilinmez yarın ne bela getirir başıma” (Dilmen, 2010: 133).

Güngör Dilmen, pek çok oyununda olduğu gibi Yol adlı oyununda da bilimin üstünlügü temasını ele almıştır. Oktay, Amerika'nın saygın üniversitelerinden biri olan Yale Üniversitesi'nde eğitim görmüş idealist bir mühendistir. Mezun olduktan sonra ülkesinin gelişimi için yurda dönmüştür ve Hamdi Bey adında bir yol yapım üstlenicisi ile birlikte çalışmaktadır. Hamdi Bey, bilimden daha çok alışılagelmiş düzene ayak uydurur ve herhangi bir uzmanlığı olmaksızın ihale kazanarak yol yapımı işiyle ilgilenir. Oktay ise, yaptığı işi bilimin sağlam temelleri üzerine oturtarak gerçekleştirmek ister. Oktay ve Hamdi Bey arasındaki anlaşmazlık, temel değer olarak bilimi öncelik almak hususundadır:

"Oktay - Bilimsel kriterler vatan toprağında da geçerlidir. Toprak katmanları çok önemli.

Hamdi - İnsan katmanları da önemli. Şu Alevi, şu Sünni köyü diyelim. Yolu iki eşit uzaklıkta geçirmeliyiz ki, iki köyden biri bize haksızlık yapıldı demesin. Kürtler huylanmasın" (Dilmen, 2010: $36)$.

Hamdi Bey, bilimin üstünlügünü yalnızca sosyolojik konumları önemsediği için değil aynı zamanda kişilerin rantınıda düşünerek reddeder. $\mathrm{O}$, yapılacak olan yolu hem Memduh Ağa'nın kuracağı petrol istasyonunun hem de Müstecip Bey'in topraklarının yanından geçirmek derdindedir:

"Oynatıcı - Yer katmanları, zemin direnç hesapları Hamdi Bey için palavraydı. 'Burası Türkiye' idi" (Dilmen, 2010: 37).

Hamdi Bey, düzene ayak uydurmuş bir ticaret adamı olsa da, ülkenin Oktay gibi bilgili ve çağdaş gençlerle ilerleyeceğinin farkındadır ve ona kişisel olarak saygı duyar.

"Hamdi -(İçten)Bu memleket sizin gibi idealist gençlerle mamur olacak, Oktay Bey oğlum" (Dilmen, 2010: 37).

Oktay, bilimin her dalına oldukça meraklı bir gençtir ve bilim adına büyük bir hayali vardır. Kültürü ve dili bozulmamış bir Hitit köyü bularak bilim dünyasını sarsmak istemektedir. Veysi, Oktay'ın bu zaafını kullanarak onu kandırır. Yolu geçirmek istedikleri bölgenin yanındaki köyün, Hitit Köyü olduğunu zanneden Oktay, yolun o bölgeden geçmesine izin verir. O, bilim dünyasının 
köye akın edeceğini ve yolun oradan geçmesi gerektiğini düşünerek mesleğindeki ilk hatayı bilimin söylediklerini gerçekleştirmemekle işler.

\section{Irkçılık ve Etnik Ayrıştırma}

Güngör Dilmen, İlse Koch adlı oyununda Nazi Almanyası'nda yaşamış gerçek bir karakter olan İlse Koch'u ana karakter olarak işlemiştir. Yazar, İlse Koch'un sadist kişiliğini savaşın soğuk yüzünü göstermek amacıyla kullanır. Irkçılık, yazarın eleştirdiği temadır.

Nazi komutanlarından birinin eşi olan İlse Koch, esir Josef ın dövmesinin sırrını merak eder. Josef ın dövmesinde eski sevgilisi Lorelei'ın adı yazmaktadır. İlse, Lorelei ile ilgili daha fazla şey merak ettikçe Josef anlatmaya devam eder. Lorelei, Alman bir kızdır ve Yahudi değildir. Lorelei ve Josef, birbirlerini çok sevmişlerdir. Almanya'da 1 rkçılık arttıkça Lorelei yavaş yavaş Josef tan uzaklaşır. Josef, ırkçllı̆̆n artma sebebini Yahudiliğin yükselişi ve Yahudilerin elde ettikleri başarılar olarak görür:

"Josef - Bizim ilk günlerimizde Yahudilik o denli sakıncalı değildi. Önemli bir Fransız söylemiş : 'Bir ülkenin kültür düzeyi, yetiştirdiği büyük Yahudilerle ölçülür,’ diye.

...

Dünyanın en büyük dâhileri Yahudiler arasından çıkıyorsa... Biz sakıncalı ırkız demektir. Karl Marx, Freud, Einstein. Her biri de kendi alanında dünyayı değisstiriyor ve de evreni..." (Dilmen, 2010: 84).

İlse Koch, Josef ın Lorelei dövmesini şairane bulur. Alman şair, Goethe'nin sık sık Buchenwald'a gelerek yakınlarındaki meşe ağacının altında şiir yazdığını hatırlatır. Josef, o ağacın artık inançlarından dolayı insanların asıldığı bir yer olduğunu söyler. İlse Koch, vurdumduymaz şekilde o ağaçta değil başka ağaçlarda insanları öldürmenin daha doğru olduğunu söyleyerek insan öldürmeyi olağan karşılar.

İlse Koch, Josef in Goethe'den çok Yahudi olduğu için Heine'yi beğendiğini iddia eder. Josef, Heine'yi tutmaktan ziyade ona tutunduğunu söyler. Josef, Alman askerleri onu almaya geldiklerinde alelacele Heine'nin bir kitabını yanına aldığını anlatır. Yazar, sanatçının inancının ve ırkının dışında sanatının değerlendirilmesi gerektiği düşüncesini Josef in repliği ile seyirciye sunar:

"Josef - ...Darda kaldı̆̆ım zaman Heine'yi çıkarıp : 'Bakın, Alman şiirinin büyük ustası Heine de Yahudiydi,' diyorum. İşitin, Almanya'yı birleștiren Bismarck ona dil uzatanlara karşı nasıl savunuyor Heine'yi : 'Adının ancak Goethe'nine yanı sıra anılabileceğini, şiirinin katıksız Alman şiiri olduğunu bu baylar nasıl unutabilirler?’” (Dilmen, 2010: 86).

Josef, Heine'nin Yahudilikten Hırıstiyanlığa geçiş sürecini İlse'ye anlatır. Heine, Hukuk Fakültesi'ni bitirdikten sonra Yahudi olduğu için iş bulamaz ve Hıristiyan olur. Yahudilere karşı olmalarıyla bilinen Protestanlık mezhebini seçer ve kendi deyimi ile "Avrupa kültürüne bir Giriş bileti”(Dilmen, 2010: 86) alır. Josef, kendisi de din değiştirerek Katolik olmasına rağmen Almanya'da esir olur. $\mathrm{O}$, din değiştirse bile dövmesinin kalıcılığı kadar kalıcı olan ırkını değiştiremediğini söyler ve esir kampında inançlarını kaybederek ateist olduğunu beyan eder:

"Josef - Yapıştırdılar işte yüreğimin üstüne şu Davut yıldızını. Şu haçımla oldum ben Hıristiyan bir Yahudi. İsa da Musa da dışladı beni” (Dilmen, 2010: 87-88). 
Yazar, ırkçılığın eleştirisinde bulunduğu gibi insanların her türlü kategorizasyonuna da karşı çıkar. Josef, her dilden adının karşılığı olan insanları dağarcı̆̆ında toplamaya çalışır. Bu şekilde kendini ve insanlığını çoğalttığını düşünür:

"İlse -Adın inancından daha önemli senin için. İlginç.

$\cdots$

Jozef - Uzaktan, gaipten adaşlarım seslenmeye başladı bana Jozef, Jozef, Yosip, Guiseppe, Yusuf... Ve ben o günden sonra Jozef adaşlarımı biriktirmeye başladım” (Dilmen, 2010: 93).

Güngör Dilmen, insanlığın dininden, ırkından, milliyetinden dolayı gruplara ayırmaktan sakınır. Yazara göre; insanlar öncelikli olarak insan olduğu için eşit olmalı ve bireyler toplumlara katkılarıyla öne çıkmalıdırlar.

Jozef, İlse'nin çizmelerini temizlerken silah sesleri duyulur. İlse, silah sesinden rahatsız olduğu için yakınlarında silahla adam öldürmeme emrini verdiğini hatırlayarak sinirlenir. $\mathrm{O}$, kamptan bir esir kaçmaya teşebbüs ettiği için öldürüldügünü düşünse de Jozef ona gerçeği anlatır. Nöbetçi askerlere kaçmaya çalışan askerleri vurdukları için prim ödenmeye başlandığından beri askerlerin esirlere uyguladığı oyunu anlatır. Askerlerden biri esirlerden birinin başındaki şapkayı derhal yıkayıp kurutmasını emreder ve şapkayı uzağa atar. Şapkasını alarak hızla uzaklaşan esiri, vurarak prim kazanırlar. Bu şekilde yazar, savaş esnasında insanların onurunu hiçe sayarak yapılan uygulamaları eleştirir.

İlse Koch, Jozef Lorelei ile birlikte olduğu gibi kendisiyle de birlikte olmasını ister. Josef, teklifini kabul etmeyince onu ve diğer dövmeli esirleri öldürmeye karar veren İlse Koch, insanlık tarihindeki en korkunç kıyımlardan birini gerçekleştirir. Esirleri öldürüp dövmeli derilerini yüzerek kendisine kişisel eşyalar yaptırır. Jozef in derisi ile kitap ciltleyip abajur yaptırır. Yazar, İlse Koch'un sadist kişiliğinin yanı sıra onun nezdinde pek çok devletin ve yöneticinin eleştirisini yapar. Jozef, oyunun sonundaki repliğinde günümüzden seslenerek İlse Koch gibilerinin tükenmediğini iddia eder ve günümüzde yapılan insanlık dışı uygulamaları kınar:

"Jozef - Benim buradan görebildiğim, çağdaş İlseler, Karl'lar, kol kola kucak kucağa demokrasi ve insanlık dersi veriyor geri kalmış toplumlara.

Didaktik olmamaya yeminli bizim yazar bile bozdu yeminini...

Kıssadan hisse, bir has'tir çekiyor böyle bir dünya düzenine” (Dilmen, 2010: 103).

Güngör Dilmen, Pantolog'ta yakın dostu olan ilk kültür bakanımız Prof. Talat Halman'ı konu alır. Onu şair, yazar ve çevirmen olarak tanıtarak onun günlük ve siyasi yaşamından kesitler sunar.

Güngör Dilmen, Talat Halman’ın siyasi yaşamıyla ilgili anekdotlarında Türk-Kürt kavramlarına yaklaşımını eleştirir. Halman, Kültür Bakanıyken İngiliz Kraliyet ailesini ağırlar. Basının ziyarete ilgisi büyüktür. Prenses, Eskimoların kendisini etkilediğini belirtmesi üzerine Halman, Eskimoların şiirlerinden örnekler sunar. Basın, Türk kültürü yerine Eskimoların şiirlerinin anlatılmasını doğru bulmaz. Halman, basının popülist yaklaşımına uyararak Eskimoların Türk olduğunu iddia eder. Basın toplantısındaki hiç kimse buna itiraz etmez. Bu örnekle, Eskimoların Türk olduğu iddiası absürt bir şekilde öne sürülerek Türk-Kürt kavramlarına yaklaşım eleştirilmiştir:

"2.Pantolon - Evet ama Sayın Bakan, kutuplardaki Türklerden önce burnumuzun dibindeki 'dă̆ Türklerini' adam etsek daha iyi olmaz mi?

1.Pantolon - Yani Kürtleri!" (Dilmen, 2010: 63). 
Halman, Kürtlerin Türk kökenli olduklarını kanıtlamak üzere ortaya atılan absürt açıklamalardan örnekler verir ve bu tezleri bilimsel çalışmalar olarak değerlendirir. Yazar, bu tezleri şovenizm olarak göstermek ister:

“1.Pantolon - İlle Türk mü olmaları gerekli?” (Dilmen, 2010: 63).

Güngör Dilmen, Kuzguncuk Türküsü oyununda azınlıkların yaşadığı sorunları işler. Çeşitli milliyetlerden insanlar bir arada huzur ve saygı ortamında yaşamaktadırlar. Öğretmenlik yapan Saranda, bu çeşitliliği sokakta macun satan adamın tablasına benzetir:

"Saranda - Bütün bu renkler beyaza kesilir.

Bakın şurda hepimiz renk renk Rumu, Ermenisi, Türkü, Yahudisi; Tanrının eli şöyle firıl çevirdi mi bizi ki çeviriyor da aslında.

Biz, Rum, Ermeni, Yahudi, Türk olmaktan önce

Insanızdır" (Dilmen, 2000: 28).

Kişiler arasındaki tartışmalar, milliyetin dışında kişisel sürtüşmelerdir. Ancak, Türk olmayanlara gavur denilse bile azınlıklar bu duruma alışmışlardır. Komşular, arkadaşlıklar, aşkların saygı çerçevesinde yürütüldüğü bir dönem olması, yazarın oyunda özellikle altını çizdiği bir noktadır. Yazar, halkın günlük yaşamındaki adil düzenin aksine yasaların uygulanması hususunda adil olunmadığı ve azınlıkların haksızlığa uğradığı fikrindedir. İmam Efendi’nin cübbesiyle dolaşması hoş görülürken Papaz Todori'nin cübbe giymesi göze batar. Din adamlarının cübbeleriyle günlük hayatlarını sürdürmeleri kıyafet yasasına aykırıdır:

"Todori - Yasa ikimiz için de geçerli değil mi?

Saranda - Gerçekçi ol Todori, biz azınlığız bu ülkede” (Dilmen, 2000: 25).

Atatürk'ün Selanik’te doğduğu eve Yunanların bomba koyduğu haberi ülkedeki huzur ve güven ortamının bozulmasına sebep olur. Devletin göz yumması ve basının tahrikleriyle bazı gençler azınlıklara karşı ayaklanır. Türk halkının bir kısmı birlikte yaşadıkları komşularına sırtını dönmez ve kendilerini korumalarına yardımcı olur:

"Saranda: ( Yaklaşan Ŭ̆ultular)

Kurt sürüleri gibiydi

Ancak biz de koyun kuzu değildik. Rumu, Yahudisi, Ermenisi ve Türkü...

Türkler ikiye ayrılırmış demek:

Saldırganlar...Savunganlar! Kuzguncuk Savunması başladı...” (Dilmen, 2000: 50).

Yaşanan 6-7 Eylül olayları sonrasında azınlıklar, memleketleri bildikleri Türkiye'den asıl yurtlarına dönmeyi düşünürler. Azınlıklar, kendilerinin hiçbir suçu olmamasına rağmen saldırıya uğramışlardır. Canlarının tehlike altında gören azınlıklar, evlerinden, işlerinden ayrılarak kendi memleketlerine dönme kararı alırlar. Türkiye'yi memleketi gibi görmüş azınlıkların evlerinden, komşularından, işlerinden ayrılması trajik görüntülere sahne olur. Azınlıkların düştüğü zor durumdan faydalanmak isteyen müteahhitler, azınlıkların evlerini ucuza alıp apartmanlar yapmak isterler. Kuzguncuk, bir süre sonra müteahhitlere dar gelmeye başlar ve başka semtlere dadanırlar. Kuzguncuk, sanatçıların merkezi haline gelir. Saranda, Kuzguncuk'u sanat ortamı haline getirenin Cengiz Bektaş olduğunu ileri sürer. Cengiz Bektaş'ın "Hoşgörünün Öteki Adı: Kuzguncuk" kitabındaki "hoşgörü" kelimesine takılıp kalan Saranda, hoşgörünün tanımı üzerine Bektaş ile bir sohbet gerçekleştirirler. Saranda, azınlık halktan biri olarak "hoşgörü” kelimesinin onda uyandırdığı duyguları paylaşır: 
"Saranda - Peki lütfen söyler misiniz, benim neyimi hoşgöreceksiniz?

Şurada evimle işim arasında gidip geliyorum,

kimsenin ruhu duymuyor varlığımı.

Neyimi hoş görüyor, neye katlanıyorsunuz?

Sabah saat sekizde, ya da akşam bește

ürkek çan seslerine mi?

Vaftiz, düğün ne söz!

Ölüm çanları da seyrekleşti.

Hoşgörü bizden efendim.

Hoşgörmeyip de ne yapacă̆ız, katlanamayan gider.

İste pankartlar asmışlar: "Ya sev, ya git!" diyorlar.

Bu kadar basit” (Dilmen, 2000: 68-69).

Saranda, azınlıkları ülkeler arasında kalmış bir yumurta olarak değerlendirir. İki ülkeden biri hafif hareketlenince, arada kalanın suçsuz azınlıklar olduğunu belirtir.

\section{Demokrasi}

Güngör Dilmen, Toplar ve Paşalar adlı eserinde iç savaş çıkararak iktidarını korumak isteyen Paşa'nın demokrasi yolundan ayrıldığı için başına gelen felaketi anlatır. Paşa, topları ülkedeki diğer partilere karşı kullanmak hazırlığındadır. Paşa'nın hedefinde asıl sol partileri bitirmek vardır:

"Silindir Şapkah - Bütün dahice taktikler basittir.

Paşa- Yabancı değilsin. Sağa biraz kuru sıkı gümbürdetiyoruz, sonra var gücümüzle, topun var gücüyle yani sola çullanıyoruz. Ortalık bize kalıyor" (Dilmen, 1996, 71).

Silindir Şapkalı, Paşa'nın iktidarı uğruna çıkarılmak istenen iç savaş için bahanesini topun şeklinden ilham alarak bulur. Güllelerin üzerinde bazı kişilerin suretleri vardır. Silindir Şapkalı, bu suretlerden yola çıkarak iç savaşı, demokrasinin izin verdiği düşünce çarpışmalarıyla özdeşleştirmek ister:

"17. Urban - Bunlar kellesel gülleler.

Silindir Șapkalı - Böylece, bir düșünce savașı verdiğimize de inandırabiliriz dünyayı" (Dilmen, 1996: 73).

Paşa, topu incelemek üzere kafasını namluya sokar ve kafası sıkışır. Kendisini kurtarması için en yakın siyasi arkadaşını ve yardımcısını usulsüzlük yaptığı dosyalarla tehdit eder. Halbuki o zamana değin yardımcısının yolsuzluklarını bilmesine rağmen menfaati uğruna sesini çıkarmamıştır. Demokrasi yolundan ayrılıp ülkeyi iç savaşa sürüklemek isteyen Paşa, topun patlaması ile canından olur. Yazar, ülkeyi demokrasi çarkından çıkarmak isteyenlerin sonunun felaket olacağını ima etmek istemiştir.

\section{7. Özgürlükler}

Güngör Dilmen, Sokrates 'Bulutlar'da adlı eserinde düşünce suçlarından dolayı yargılama yapılmasının eleştirisini yapar. Sokrates, karşısındaki insana sorular sorarak çeşitli düşünceler oluşturma yoluna giden bir aydındır. $\mathrm{O}$, kendine has bir yöntem olarak geliştirdiği soru sorma 
tekniği olan "düşünce doğurtma" (Dilmen, 2012: 13) sistemi ile döneminin önemli kişiliklerinin tepkisini çekerek gençliğin inançlarını köreltip onları mutsuz etmekle suçlanır. Onun yargılanmasında diğer büyük etken, kendisini çekemeyen aydınlardır:

"Sokrates - Meletos, kendisini şair sandiğg için bana düşman.

Anütos, politikacılar adına bana kırgin.

Lükon ise hatipler adına küskün.

Kendimi böyle kişilere bir türlü beğendiremedim.

Beğendirmeye de yok niyetim.

Ben bunu bilir bunu söylerim.

Isște düşündüklerimi açık açık söylemem.

Asıl nedeni başıma bu belaları getiren"(Dilmen, 2012: 40).

Yargılamanın neticesinde ölümle cezalandırılan Sokrates, tutulduğu mağaradan kaçmayı kendine yediremez ve zehri içerek ölür. Yazar, burada aydınların yaşama dair her şeyi sorgulamanın asıl görevleri olduğu iletisini eserinin ana teması olarak seyirciye sunar ve Sokrates'in son sözlerini oyundaki tüm kişilere koro halinde söyleterek iletinin gücünü arttırır:

"Bütün Kişiler - “Sorgulanmayan bir yaşam yaşamaya değmez." dedi” (Dilmen, 2012: 54).

Güngör Dilmen, İttihat ve Terakki adlı eserinde devlet idaresinin sağlıklı yürümesinin ön şartı olarak özgürlüklerin tanınmasını koşar. Devlet idaresi, yabancı devletlerden alıntı yapılarak yerleştirilmeye çalışılan değerler yerine, mevcut yönetim tarzının özgürlüklerle yoğrulması ile ideale ulaştırılabilir. Özgürlüklerin yerleştiği ülke yönetiminde, kişisel hırslara ve yolsuzluklara meydan verilmez. Oyununda, Abdülhamit ve Talat Bey'in Osmanlının geleceği hakkındaki konuşmaları sahnenin gerçeküstü bir alana dönüştürülmesiyle yapılır. Köhne bir malikaneyi ayakta tutmanın yollarını konuşurlarmış gibi Osmanlının geleceğini tartışırlar. Abdülhamit elinde bir çekülle çökmekte olan malikanenin duvarlarını ölçerek bu yapıyı nasıl kurtaracağını hesaplar. Talat Bey'i durduğu yerin de çökeceği konusunda uyarır. Talat'ın göçmelerin nerden başladığı sorusuna "Avrupa'dan getirttiğiniz özgürlük denen şu ağır kristal avizeyi kubbeye asarsanız böyle olur işte."(Dilmen, 2003: 117) der. Abdülhamit'e göre kubbe bu ağırlı̆̆ taşıyamayacaktır ve onu tahtan indirdikleri takdirde onların da git gide kendine benzeyecekleri konusunda uyarır. İttihat ve Terakki toplantısında topluluğun içinde kişisel tutkulara yer olmadığına dair yapılan konuşmayı hatırlatarak bu konuda yanılacaklarını ve zaman içinde yaptıkları devrimin Abdülhamit devrinin kopyası olacağını iddia eder. Nitekim öyle olmuştur ve iktidarı ele geçiren İttihat ve Terakki kişisel tutkulara tutsak olmuştur.

Güngör Dilmen'in eserlerinde, baskıcı yönetimler eleştirilen konulardan biri olmuştur. İttihat ve Terakki oyununda İttihat ve Terakki yöneticilerinden Talat Bey'in partiyi tutmayan memurların işlerinden atılacaklarını söylemesi diğer bir yönetici olan Mithat Şükrü Bey tarafından doğru bulunmaz. İçlerinde benimsemeden yalnızca dış görünüşte İttihatçı görünen insanların bir işlerine yaramayacağını söyler. Talat Bey düşüncelerini şöyle savunur:

"Talat Bey - ....Memur yüzyıllardan beri yalnız midesiyle bağlıdır bir yönetime. Ekmeği değil mi biz veriyoruz... biz de kendimize bağl memurlar isteriz kendimize" (Dilmen, 2003: 193).

\section{8 . Rüşvet}

İttihat ve Terakki oyununda devlet kademelerinde rüşvet meselesi eleştirilir. Sultan Reşat, Abdülhamit tahttan indirildikten sonra tahta geçebilmek için Prens Sabahattin'in rüşvet talebiyle 
karşılaşmıştır. Prens Sabahattin, Reşat’a İngiliz bankerden elli bin altın borç alıp ona vermesini ve tahta geçince devlet hazinesinden geri ödemesini ister. İttihat ve Terakki'nin Sultan Reşat'ı tahta geçirmesiyle rüşvet vermesine gerek kalmayan Reşat bu duruma şükreder.

Osmanlı'nın bu döneminde rüşvet meselesi devlet işlerinin yürümesi için olağan duruma gelir. Öyle ki yokluk içinde savaşan askerler için gönderilecek zeytinyağ için bile rüşvet döner. Talat Bey, Enver Paşa'ya askerler açlık ve sefalet içinde savaşırken aldığı rüşvetlerle zengin olan İsmail Hakkı'yı kovmasını ister. Enver Paşa ise, içinde bulundukları durumun hiçbir değişikliğe müsait olmadığını belirtir. Abdülhamit yeniden sahneye gelir ve namuslu bir insan ararken kurulu düzenin bozulmamasını gerektiğini ve yüzyıllardır devam eden bu çarkın işletilmesi gerektiğini söyler:

"Abdülhamit - ...devlet hizmeti bir rüşvetler sisteminin düzenli çalışması demektir. İsmail Hakkı Paşa'nın tuttuğu, güvendiği adamlar vardır, bu adamların adamları vardır, onların dahi adamlar vardır. Ve rüşvetler bu silsile-i meratip boyunca alınıp verilir. Usulünce, töresince üleşilir ve bu arada büyük ölçüde çalınmış da olsa Mehmetçiğin eline ulaşır biraz ekmek” (Dilmen, 2003: 176).

Yakup Cemil, Enver Paşa'ya kendisine verilmeyen görevlerden dolayı memnuniyetsizliklerini iletmek için gittiğinde yağ toplayıcı Hacı Emin gelir. Enver Paşa’nın yardımcısı Kara Kemal'le konuştuğunu zanneden Hacı Emin onu İsmail Hakkı Bey’in gönderdiğini ve askerin tek yağ temin edicisinin kendilerinin olacağını ve onlara da bu işin sonunda belli pay düşeceklerini söyler. Yakup Cemil durumu hiç bozmadan onlarla rüşvet pazarlı̆̆ı yapar. Anlaşmaya vardıklarını düşünen Hacı Emin belgelerin hemen imzalanmasını ister. Yakup Cemil'in imzası ise silahıdır. Silahını Hacı Emin'e doğrultur ve oracıkta onu öldürür. Talat bir hukuk devleti olduklarını ve eğer Hacı Emin bir suç işlediyse bunun cezasını yargıçların vermesi gerektiğini söyler. Halbuki bu sözleri söyledikleri kişi İttihat ve Terakki’nin suikastlarını gerçekleştiren kişidir. İkiyüzlü bu tutuma karşı Yakup Cemil, elini yağa bulamaktansa kana bulamayı tercih ettiğini söyler.

Yakup Cemil'in Enver Paşa'ya asıl geliş amacı, bağımsız bir kuvvetin başına verilip savaşa gitmek için izin almaktır. Enver Paşa bu isteği kabul etmediğinde Yakup Cemil'in cevabı Enver Paşa'nın devlet kademesinde gerçekleştirdiği torpilleri açıklar niteliktedir:

"Yakup Cemil - 'Yaparsın yasayı olur yasa' diyen sen değil miydin? Kardeşin Nuri'yi binbaşılıktan paşaliğa yükselttin, yasa vardı elinde. Amcan Halil'i paşa yaptın, yasa vardır elinde. Sen kendin ayn ay içinde yarbaylıktan paşalığa yükseldin -albaylık ne oldu arada?- yasa vardı eline. Biz ki soysuz soyluları alaşağı etmek için giriştik bu devrime, sen damat oldun saraya” (Dilmen, 2003: 182).

\section{Kumalık Kavramı}

Güngör Dilmen, Kurban adlı oyununda toplumsal bir sorun olan kumalık meselesini tema olarak belirlemiştir. Kırsal kesimlerde evlilikler genellikle görücü usulü yapılsa da, Zehra ve Mahmut birbirlerini severek evlenmişlerdir. Bir yuva kurmuşlar ve birlikte tarlalarında çalışarak mal mülk edinmişlerdir. Mahmut, Zehra'dan başka bir kadına aşık olmasına rağmen evine ve çocuklarına bağlı, şefkatli bir adamdır. Gülsüm'le evlenecek olmasından dolayı Zehra'ya karşı bir suçluluk duygusu hissetmektedir. Toplum arasında kuma getirmenin olağan bir durum olarak kanıksanması, Mahmut'un vicdanını rahatlatması için vesiledir:

"Zehra: Ben neyim evin içinde?

Mahmut: Onsuz yapamam, Gülsüm kanıma buyruk.

Zehra: (Daha yüksek) Ben neyim bu evin içinde?

Mahmut: Senin yerin ayrı. İlk göz ă̆rım, çocuklarımın anası. 
Zehra: Çocukları doğurmuş olmaktan öte yerim yok mu evin içinde?

Mahmut: Eve yeni bir kadın getiren erkek ben miyim köyde?"(Dilmen,2008: 38).

Zehra, o gece korkunç rüyalar görür. Halime ve Kadınlar, Zehra için Gülsüm’ü öldürüp Mahmut'un yatağına bırakmışlardır. Mahmut öptükçe Gülsüm canlanır. Zehra, kadınların ona kumpas kurduğunu zanneder. Gülsüm'ün aslında canlı olduğunu, onu ölü gibi gösterip eve aldırdıklarını düşünerek tepki gösterir. Kadınlar Zehra'ya, Gülsüm'le iyi geçinirlerse her şeyin daha kolay olacağını söyler. Zehra ise, bu rüya ile Gülsüm'ün ayağını evin eşiğinden attırmamaya ant içer.

Kuma meselesi köyde o kadar kanıksanmıştır ki kadınlar bile bu duruma tepki göstermemektedir. Köyün yaşllarından Halime Nine ve oyunda koro vazifesi gören kadınlar, Zehra'ya moral vermek için yanına gelirler. Halime, ilk zamanların zor olacağını ama daha sonra Gülsüm’e alışacağını söyler.

Zehra, köyde üzerine kuma gelen ilk kadın değildir. Kadınlar Zehra’nın ne hissettiğini anlasalar da içindeki duyguların dışavurumunun olacağını düşünmezler. Halime, daha önce üzerine kuma getirilecek olan bir kadının ah çekmesiyle düğün alayının taş kesildiği efsanesini anlatır. Dügün alayı taş kesilmesine rağmen, bu efsanede kadının bir rolü ve aksiyonu olmamıştır. Aksine kadın, o kadar çaresiz durumdadır ki ah çekmekten başka yapabildiği bir şey yoktur. Oysa; Zehra, bu pasifliği kabullenmeyecektir. Halime, oyunun sonundan haber verircesine, şu sözleri sarf etse de o bile olayların geleceği noktayı tahmin etmemektedir:

"Halime: Bugün bir şeyler olacak öyleyse. Bin, bin yıldır

Anadolu kadınının sustuğu çı̆̆lık

belki senin yüreğinden fışkırır" (Dilmen, 2008: 55).

\section{Sonuç}

Güngör Dilmen, tiyatro eserlerinde mitolojiyi ve tarihi konuları temel alırken toplumun yaşadığ 1 siyasi, kültürel ve ideolojik problemlere çareler arama çabasındadır. Onun tiyatro eserleri bu bağlamda uyarıcı ve yol gösterici bir yapıya sahiptir. Yazar, geçmiş dönemlerde ve farklı coğrafyalarda insanlığın yaşadığı dram ve trajedileri ele alırken aslında insanlığın evrensel nitelikteki yaralarına temas eder, geçmişte yaşanan örneklerle bugünün sorunlarına ş̧ık tutmaya çalışır. Güncel sorunlara evrensel çözümler üretir. Bu çözümün temel kavramı kendi olmaktır. Yazarın bakış açısına göre kim olursa olsun dışarının her türden yönlendirmesi kimliğin gelişiminde en büyük engeldir. Bu çerçevede toplumun kendi kültürüne sahip çımayarak Batının kültür emperyalizmine kapılmasını eleştirir. Avrupa ve Amerika'nın kendi menfaatlerini üstün görerek diğer milletleri sömürmelerine dikkat çekerek belirli bir bilinç oluşturmak ister. Yazar, ideal dünya düzeninin inançlarla değil akıl ve bilimle gerçekleşeceğini düşünür, aklı ve bilimi daima inançların üzerinde tutar. Ona göre toplumların ve devletlerin güçlü olması yozlaşmış düşünce ve inançlardan kurtulmalarına bağlıdır. Eserlerde sorumsuzca davranan yönetsel erkin eleştirisine yer verilirken bireysel manada bilinçlenmenin önemine dikkat çekilir.

Güngör Dilmen'in eserlerinde önem verdiği konulardan biri de kadındır. Toplumun, yanlış fikirlerle kadına dayattığ 1 roller eleştirilir. Kadının kuma olarak istismar edilmesine ve her türlü baskı ile özgürlüğünün kısıtlanmasına karşı çıkılır. O, tiyatrolarında insanı ve toplumu yok sayan, insanın ve toplumun varlığını kendi eliyle gerçekleştirmesine engel olan her türlü anlayışı reddeder. Bu tarz evrensel sorunların çözüm yollarını, estetik boyutta söylevci bir yaklaşıma 
yönelmeden işler. Toplumsal temalı tiyatrolarında bireyi tahakküm altına alan her tür ideolojik görüşün ve dini referans alan düşüncenin, özgürlükleri kısıtlayan çıkar odaklı yapılanmaların sorgulanmasının gerekliliğine vurgu yapmıştır. Devletlerin sömürü amaçlı emellerinden, azınlıkların haklarına kadar dünyanın yönetiminde belirleyici olan, insanın varlığını ve kimliğini yok sayan saldırıların ancak insanın kendini, kendi aklı ve iradesi ile tanımladığında durdurulabileceğini göstermeye çalışmıştır. Tiyatrolarında bireyin özgürleşmesine çeşitli bahanelerle engel olunarak onu sömürmeyi esas alan her tür sisteme karşı bir duruş gösteren Güngör Dilmen, kimliğini kendi iradesi ile gerçekleştirmenin evrensel bir gereklilik olduğuna inanır.

\section{Kaynakça}

Altun, H. (1999). Bir Reji Çalışması: Akad’ın Yayı (Yayımlanmamış Yüksek LisansTezi). Ankara: Ankara Üniversitesi Sosyal Bilimler Enstitüsü.

Aktaş, Ş. (2013). Anlatma Esasına Dayalı Edebi Metinlerin Tahlili. Ankara: Kurgan Edebiyat Yayınları.

And, M. (1983). Cumhuriyet Dönemi Türk Tiyatrosu, İstanbul: Türkiye İş Bankası Kültür Yayınları.

Çalışlar, A. (1995). Tiyatro Ansiklopedisi, Ankara: T.C. Kültür Bakanlığı Yayınları.

Çekiç, S. , \&Doltaş, D. , \& Halman, T. (2010).Güngör Dilmen Bildiri Kitabı,Güngör Dilmen'in 50. Sanat Yılı Sempozyumu, Birinci Baskı, İstanbul: Mitos Boyut Yayınları.

Çetin, N. (2008). Roman Çözümleme Yöntemi, Altıncı Baskı, Ankara: Öncü Kitap.

Dilmen, G. (1996). Toplu Oyunları 3, Birinci Baskı, İstanbul: Mitos Boyut Yayınları.

Dilmen, G (1998). Toplu Oyunları 4, Birinci Baskı, İstanbul: Mitos Boyut Yayınları.

Dilmen, G. (2000). Toplu Oyunları 5, Birinci Baskı, İstanbul: Mitos Boyut Yayınları.

Dilmen, G. (2002). Osmanlı Dram Kumpanyası, Birinci Baskı, İstanbul: Mitos BoyutYayınları.

Dilmen, G. (2003). Toplu Oyunları 6, Birinci Baskı, İstanbul: Mitos Boyut Yayınları.

Dilmen, G. (2007). Keçitürküsü, Birinci Baskı, İstanbul: Cem Yayınları.

Dilmen, G. (2008). Toplu Oyunları 2, İkinci Baskı, İstanbul: Mitos Boyut Yayınları.

Dilmen, G. (2009). Galileo’nun Günahları?, Birinci Baskı, İstanbul: Mitos BoyutYayınları.

Dilmen, G. (2010). Toplu Oyunları 1, Birinci Baskı, İstanbul: Mitos Boyut Yayınları.

Dilmen, G. (2011). Canlı Maymun Lokantası, Birinci Baskı, İstanbul: Mitos Boyut Yayınları.

Dilmen, G. (2012). Sokrates “Bulutlar"da, Birinci Baskı, İstanbul: Mitos Boyut Yayınları.

Dilmen, G. (2016). Toplu Oyunları 1, Birinci Baskı, İstanbul: Mitos Boyut Yayınları.

Dilmen, G. (2017). Deli Dumrul, Birinci Baskı, İstanbul: Mitos Boyut Yayınları.

Dilmen, G. (2017). Ben Anadolu, Birinci Baskı, İstanbul: Mitos Boyut Yayınları. 
Dilmen, G. (2017). Hasan Sabbah, Birinci Baskı, İstanbul: Mitos Boyut Yayınları.

Doğan, D. Mehmet (1990). Büyük Türkçe Sözlük. Ankara: Rehber Yayınları.

Göktaş, S. (2015). Güngör Dilmen’in Mitolojik Dünyası, İstanbul: Yeni Yayınevi.

Keçeli, F. (2003). Güngör Dilmen'in Oyunlarında "Mitolojik, Tarihsel ve Fantastik Olanın" Kullanımı. Tiyatro Araştırmaları Dergisi.

Yaycıoğlu, M. (2005). Güngör Dilmen’le Söyleşi. Tiyatro Araştırmaları Dergisi 20, s.129-142. 